\title{
Asset Utilization and Company Performance
}

\author{
Christian Herdinata \\ International Business Management, Universitas Ciputra, Surabaya, Indonesia \\ e-mail: christian.herdinata@ciputra.ac.id
}

\begin{abstract}
This study examines the expropriation that occurs in asset utilization due to tunneling. This study aims to examine the effect of asset utilization on company performance. This study used a sample of 130 companies in Indonesia to examine the effect of asset utilization on company performance. This research uses simultaneous equation model with Three-Stage Least Square technique. The results showed that asset utilization has a positive and significant effect on company performance. The result of the research shows that asset utilization which is managed and well controlled has influence to improve company performance.

Keywords: company performance, asset utilization, expropriation, tunneling
\end{abstract}

\section{INTRODUCTION}

Expropriation can be done by majority shareholder through company policy. Shleifer and Vishny (1986) argue that majority shareholders are more interested in using their controls to gain private benefits. When the private benefits of control are large, the majority shareholder will seek to allocate the company's resources to generate the private benefits. The way to obtain private benefits is through tunneling. Johnson et al. (2000) defines tunneling as the transfer of resources out of the enterprise for the benefit of the controlling shareholder. Transactions with related parties tunneling, among others: (1) cash payment transactions; (2) asset purchases; (3) sale of assets; and (4) asset exchange (Cheung et al., 2006; Cheung, Qi, and Rau., 2009). Based on these problems, agency conflicts in asset utilization if not resolved with the correct mechanism and do not find the right solution, it will affect the company performance. Therefore, through this research is expected to get the right solution to do the control mechanism to asset utilization to reduce agency conflict. The higher intensity of agency conflict that occurs will affect the de- crease in corporate performance due to increased agency costs and conversely the lower the intensity of the conflict will affect the increase in corporate performance due to decreased agency costs. The issue of agency conflict needs to be examined and found the right solution to perform a control mechanism on asset utilization that affects the company's performance. Therefore, this study is focused on resolving agency conflicts that occur within the asset utilization due to tunneling.

\section{LITERATURE REVIEW}

\section{Asset Utilization}

Asset utilization is a measure of the company's ability to produce (Ellis, 1998). Nonutilized firm assets represent a loss in relation to investments caused by inefficient use of assets. In addition, assets that are not being properly utilized will have an effect on increasing agency costs because managers do not act in the best interests of the owners in using assets owned by the company (Fleming, Heaney, and McCosker, 2005). Previous research has shown that manager behavior can be monitored by 
shareholders to ensure that assets have been used efficiently to increase shareholder value (Ang, Cole, and Lin, 2000; Fleming, Heaney, and McCosker, 2005; Singh and Davidson, 2003). This phenomenon is in line with the assumption that the use of free cash flows for excessive investment activities that are not related to the main activities of the company will contribute to the level of efficiency in the use of assets owned by the company. Several studies related to asset utilization were performed by Ang, Cole, and Lin (2000); Ade, Yustina (2008); Jelinek and Struerke (2009); Iskandar, Bukit, Sanusi (2012) examines the effect of ownership structure on asset utilization. In addition, Ang, Cole, and Lin (2000); Jelinek and Struerke (2009); Wang Goerge Yungchih (2010); Iskandar, Bukit, Sanusi (2012) also examines the effect of debt policy on asset utilization. Another study was conducted by Wang, Goerge Yungchih (2010); Abdulla, Shah, and Khan (2012); Pouraghajan, et al (2013) examined the effect of asset utilization on firm performance.

\section{Company Performance}

The quantity of performance is a measure of the success of management in managing the company (Mahadwarta, 2004). Performance is an important part of investors' motivation to invest in companies. Therefore, which also needs to be considered is the amount of return that will be obtained by shareholders (Ismiyanti, 2007). Company performance is realized in various activities to achieve corporate objectives because each activity requires resources, then the performance of the company will be reflected from the use of resources to achieve corporate goals (Herdinata, 2006). Therefore, the company's performance is the measurement of the company's achievement caused by the complex and difficult decision-making process of management, because it involves the effectiveness of capital utilization, efficiency, and profitability of the company's activities. Cui and Mak (2002); Zeitun and Tian (2007); Abor Joshua (2007); Rayan, Kuben (2008) Jelinek and struerke (2009); Wellalege and Locke (2011); Abdullah, Shah, and Khan (2012) use ROA as a measure of performance. On the other hand, Faccio and Lasfer (1999); Zeitun and Tian (2007); Rayan, Kuben (2008); Wang, Goerge Yungchih (2010); Bosses, Pendleton, and Toms (2011) use return on equity as a measure of company performance. On the other hand, Morck, Randall (1987); McConnel and Servae (1990); Faccio and Lasfer (1999); Cui and Mak (2002); Abor Joshua (2007); Koiki and Said (2011); Ruan, Tian and Ma (2011); Wellalege and Locke (2011) use Tobin's Q as a measure of company performance. The use of Tobins $Q$ describes what management will accomplish in the future (Hu and Izumida, 2008b). Bozec and Laurin, (2008) and Morck et al. (1998) states that the value of Tobins $Q$ captures the existence of agency costs arising from different ownership structures. High Tobins Q indicates that the company has good growth because of the use of good assets in the company. Likewise Chen (2001) states that the value of Tobins Q shows the effectiveness of the use of resources within the company. The smaller the value of Tobins $Q$ shows the greater the agency conflict between the majority and minority shareholders in the company. The magnitude of the agency conflict between the majority and minority shareholders reflects the expropriation made by the majority shareholders through management of minority shareholders. Conversely, the greater the value of Tobins $Q$ shows the more effective monitoring by the majority shareholder of the company's management. 
Relationship of Asset Utilization with Company Performance

The relationship between asset utilization on company performance can be influenced by transnational-related transactions that are indicated by tunneling. Tunneling can occur based on tunneled resources such as cash flow tunneling and asset tunneling (Atasanov et al., 2007). Cash flow tunneling is a transaction that transfers cash or current assets to a related party (Atasanov et al., 2007). Transactions relating to transactions that are indicated as cash flow tunneling include the purchase or sale of goods or services, payment of services to related parties, and accounts receivable to related parties. Asset tunneling is a transaction that transfers long-term (tangible or intangible) assets from (to) the company to (from) related parties (Atasanov et al., 2007). Transactions related to the assets of tunneling assets are transactions of purchase or sale of assets to related parties. Each form of tunneling has a different influence on financial performance. Asset tunneling effect on the balance sheet while cash flow tunneling effect on income statement. Jian and Wong (2003) found that firms use accounts receivable transactions on a related party as a tunnel to transfer the company's outgoing resources. Aharony et al. (2005) found that loan transactions to related parties were used as a means of tunneling after the IPO. Cheung, Jing, and Lu (2009) find empirical evidence that public companies in Hong Kong perform asset tunneling through related party transactions. A public company transacts assets with related parties at a lower price than on an asset transaction with an independent party. The Company purchases assets from related parties at higher prices than on independent party transactions, on the other hand the company sells assets to related parties at a lower price than to independent party transactions. The sale of assets to the related party below the fair price (tunneling out) will affect the financial performance but indirectly, through the loss of potential synergies between the assets in-tunnel and the remaining assets (Atasanov et al., 2007). Purchase of assets from related parties above the fair price (tunneling in) will reduce the profitability of the company. Purchasing assets above fair value increases the carrying amount of assets and increases depreciation expenses, so the joint effect will reduce return on assets. On the other hand, through the application of control mechanisms to asset utilization through institutional ownership and debt policy, it effectively and efficiently controls asset utilization so as to positively affect company performance. Therefore, an indication of the transfer of resources out of the company through tunneling does not occur. Therefore, a high increase in asset utilization will be in line with the high performance of the company as a result of the application of strong control mechanisms through institutional ownership and debt policy by the company. Some studies have found that asset utilization has a positive effect on company performance, among others: Wang, Goerge Yungchih (2010); Abdulla, Shah, and Khan (2012); and Pouraghajan, et al. (2013). The hypothesis of this research are:

Hypothesis 1: Asset Utilization Influence Positive and Significant to Performance Company

\section{RESEARCH METHODOLOGY}

The data used in this research is the company's financial statement data, among others: from balance sheet, income statement, cash flow statement, and financial statement note, and capital market data. All financial report 
data is obtained from Indonesian Capital Market Directory 2001-2016 period and Indonesian Securities Market Database published by Economic Faculty of Gadjah Mada University, Indonesia. Furthermore, for capital market data obtained from the report of Indonesia Stock Exchange. The sample used in this research are: (1) Companies in Indonesia that have been audited from 2001 to 2016 and not included in the financial industry; (2) The company under study provides complete financial statement data information for all periods of research; (3) The company under study is not in the process of acquisition, merger and delisting; (4) The firms studied provide capital market data information for all periods of study. The following sample selection process has been done as many as $\mathbf{1 3 0}$ companies. Variables in this study include:

1. Institutional ownership

Institutional ownership is expressed in symbol INST_OWN. The use of institutional ownership percentage refers to Crutchley, et al (1999) studies. The proportion used to calculate the percentage of institutional ownership (INST_OWN), as follows:

INST $_{\text {OWNt }}=$ Total Institutional Ownership $/$ Total Shares Stocks ${ }_{t}$ x 100\%

2. Debt Policy

The proxy of debt policy is total debt divided by total assets referring to Abor (2007). Debt policy is expressed in the symbol of LEVERAGE. The formula used to describe the debt policy, as follows:

LEVERAGE $_{\mathrm{t}}=$ Total Debt/Total Asset $\mathrm{t}$ x $100 \%$

3. Asset Utilization

The use of proxy asset utilization refers to Wang (2010). Asset utilization is expressed in the symbol ASSET_UT. The formula used to describe asset utilization (ASSET_UT), as follows:
ASSET_UT $_{t}=$ Total Sales/Total Assets ${ }_{t} \mathrm{x}$ $100 \%$

4. Company performance

The use of Tobin $\mathrm{Q}$ proxy refers to Douma et al., 2006; Thomsen, 2004; Chen, 2001; and Wiwattanakantang, 2001. Company performance is expressed in the symbol that is Q. The formula used to describe the company's performance (Q), as follows:

$\mathrm{Q}_{\mathrm{t}}=$ (Market Value of Equity $_{\mathrm{t}}+$ Total Debt $\left._{t}\right) /$ Total Asset $t_{t}$ 100\%.

5. Return on Asset

Return on Assets ratio used in this study refers to research Hermeindito (2012). The formula used to describe Return on Assets, as follows:

$\mathrm{ROA}_{\mathrm{t}}=$ Net Profit $_{\mathrm{t}}$ Total Assets $\mathrm{t}_{\mathrm{t}} \mathrm{100 \%}$... (1.5)

6. Asset Structure

Asset Structure used in this study refers to research Hermeindito 2004. The formula used to measure the size of the company, as follows:

$\mathrm{SA}_{\mathrm{t}}=$ Total Fixed Assets/Total Assets $\mathrm{x}$ $100 \%$

7. Return on Invested Capital

The Return on Invested Capital ratio used in this study refers to the research of Chan (2001) and Stephen and David (2009). The formula used to describe Return on Invested Capital (ROIC), as follows:

ROIC $_{t}=(\text { NOPAT }- \text { Dividends Paid })_{t} /($ Long Term Debt + Total Equity - Retained Earnings) $)_{\mathrm{t}} 100 \%$

Information:

NOPAT $=$ Net Operating Profit After Taxes NOPAT $_{t}=(\text { Profit after tax })_{t}+($ Interest paid)

8. Managerial ownership

Managerial ownership in this research in the form of dummy variable is the value of 1 for 
companies that have managerial ownership and 0 for others. This refers to research Hermeindito (2012). Managerial ownership is expressed in the symbol MGR_OWN_ DUM.

This research uses simultaneous equation model with four empirical equations developed and tested based on research hypothesis. This simultaneous equation model considers non-linear functions in institutional ownership variables and debt policy toward asset utilization and firm performance. In addition, it also considers the interdependence relationship between institutional ownership and debt policy to examine the control mechanisms in agency perspectives on asset utilization and firm performance. These four empirical equations can be formulated, as follows:

$\mathrm{Q}=\alpha_{1}+\beta_{11}$ ASSET_UT $+\beta_{12}$ INST_OWN

$+\gamma_{11}$ INST_OWN $^{2}+\beta_{13}$ LEVERAGE +

$\gamma_{12}$ LEVERAGE $^{2}+\delta_{11}$ MGR_OWN_DUM

$+\delta_{12} \mathrm{SA}+\delta_{13} \mathrm{ROIC}+\delta_{14} \mathrm{ROA}+\varepsilon_{1}$

Information:

$\alpha, \beta, \gamma$, and $\delta=$ Parameter Coefficients

$\varepsilon=$ Residual

$\mathrm{Q}=$ Company Performance

ASSET_UT $=$ Asset Utilization

INST_OWN = Institutional Ownership

INST_OWN $^{2}=$ Institutional Ownership of Squares

LEVERAGE $=$ Debt Policy

LEVERAGE $^{2}=$ Debt Squares Policy

MGR_OWN_DUM = Managerial Ownership Dummy

ROIC $=$ Return on Investment and Capital

$\mathrm{SA}=$ Asset Structure

$\mathrm{ROA}=$ Return on Asset
This research uses simultaneous equation model with Three-Stage Least Square technique to test the research hypothesis. To analyze the identification capability of the existing simultaneous equation model the estimated reduced form coefficient describes an endogenous variable only a function of an exogenous variable (Gujarati and Porter, 2012: 382). When this can be solved then the equation has been identified (identified). In addition, simultaneous equation models in the study are identified by order and rank conditions of identification to ensure identifiable capabilities (Gujarati and Porter, 2012: 382).

\section{DATA ANALYSIS AND DISCUSSION}

Hypothesis 1 estimates that asset utilization affects company performance. This hypothesis is tested by estimating based on simultaneous equations model and supported by quadratic model. Table 1 presents the results of hypothesis testing 1 which shows the effect of asset utilization on company performance with control variable that is managerial ownership dummy, asset structure, and return on invested capital, return on asset. The result of the fourth hypothesis test by using simultaneous equation model shows that asset utilization have positive and significant effect to company performance. This suggests that the control mechanisms carried out on asset utilization through institutional ownership and debt policy will affect the company's performance. The test result with simultaneous equation model shows that the asset utilization $(\beta 11=1,5488)$ asset coefficient is positive and significant at significance level of $1 \%$. Thus, hypothesis 1 which states that asset utilization has a positive effect on company performance is supported. 
Table 1 Simultaneous Equation Model Test Results

\begin{tabular}{|c|c|}
\hline Variabel & $\mathrm{Q}$ \\
\hline INTERCEPT & 5,1115 \\
& $(3,11) * * *$ \\
ASSET_UT & 1,5488 \\
& $(2,59) * * *$ \\
INST_OWN & $-19,4296$ \\
& $(-3,0) * * *$ \\
INST_OWN 2 & 17,4662 \\
& $(3,1) * * *$ \\
LEVERAGE & 2,1356 \\
& $(5,39) * * *$ \\
LEVERAGE 2 & $-0,0948$ \\
& $(-1,61)$ \\
SA & 0,7593 \\
& $(7,03) * * *$ \\
ROIC & $-0,1259$ \\
& $(-2,83) * * *$ \\
ROA & 1,0944 \\
& $(8,12) * * *$ \\
MGR_OWN_DUM & $0,3998 * *$ \\
& $(2,94) * * *$ \\
\hline R-squared & 0,3404 \\
Adj. R-squared & 0,2711 \\
\hline
\end{tabular}

Information:

$$
\begin{aligned}
& * * *=\text { sig. } 1 \% \\
& * * \quad=\text { sig. } 5 \% \\
& * \quad=\text { sig. } 10 \%
\end{aligned}
$$

When asset utilization can be properly controlled it will affect the company's performance. Therefore, the active monitoring function within the company becomes important so that expropriation through tunneling can be reduced and even not. The action will have a positive effect on the company's performance. Here is an explanation of the indication of tunneling that can occur, such as PT SUN makes transactions with PT BBA and both have the same controlling shareholder that is family company of PT STA. In addition, PT SUN and PT BBA have in common the person who serves as a commissioner and director who is held by a family member of the controlling shareholder. PT ASA through its subsidiary PT SUN has entered into a sale and purchase agreement with PT BBA to purchase $80 \%$ of PT EFA shares and $70 \%$ of PT EFI shares. Furthermore, PT SUN also paid off all debts of PT EFA and PT EFI to PT BBA. Total agreed sale and purchase transactions for stock purchases and debt payments amounting to Rp985,000,000,000,. The payment amounted to Rp950,000,000,000,used to purchase PT EFA and PT EFI shares. Whereas PT EFI and PT EFA have a bad performance. PT EFI has a loss of Rp5.000.000.000,and PT EFA has a loss of Rp7.000.000.000,- and the purchase is above the fair price. Furthermore, Rp35,000,000,000,- is used to repay the debts of PT EFA and PT EFI to PT BBA. On the other hand, PT STA as a family company actually has a total cash flow right in PT BBA 100\% through PT SOS and PT RIS, while the total cash flow right in PT SUN is 60\%. The controlling rights of the controlling shareholder's cash flow is greater in PT BBA than in PT SUN. These cash flow rights differences encourage tunneling of resources from PT SUN with low cash flow rights to PT BBA with high cash flow rights. Based on the events that occur, the tunneling indication that occurred as follows: (1) transactions conducted PT SUN pertained as cash payment transactions to the related party ie PT BBA by issuing cash to buy shares of PT EFI and PT EFA which has poor financial performance and buying above fair price. The transaction actually causes losses in PT SUN and noncontrolling shareholders (PT TRA) and public shareholders; (2) PT SUN pays PT EFI and PT EFA debts to PT BBA. The transaction is beneficial to the controlling shareholder (PT STA) due to outflow cash flow from PT SUN which has a low cash flow right flowing to PT BBA having high cash flow right; (3) ownership of the company (PT SUN) and related parties (PT BBA) are owned by the same owner, namely the family company 
(PT STA); (4) there are similarities between commissioners and directors held by family members of the controlling shareholder (PT STA) at PT SUN and PT BBA.

The relationship between asset utilization on company performance can be influenced by transnational-related transactions that are indicated by tunneling. Cash flow tunneling can be performed by a related party that transfers cash or current assets to a certain party (Atasanov et al., 2007). Transactions related to cash flow tunneling may occur in the form of purchases or sales of goods or services, payment of services to related parties, and receivables to related parties (Atasanov et al., 2007). Other things that can be done through related parties transactions are the tunneling assets that move the long-term assets (tangible or intangible) from (to) the company to (from) related parties (Atasanov et al., 2007). Transactions related to the assets of tunneling assets may be transactions of buying or selling assets to related parties. Each form of tunneling has a different influence on financial performance. Asset tunneling effect on the balance sheet while cash flow tunneling effect on income statement. Tunneling occurs causing corporate losses that affect the company's performance. Jian and Wong (2003) found that firms use accounts receivable transactions on a related party as a tunnel to transfer the company's outgoing resources. Aharony et al. (2005) found that loan transactions to related parties were used as a means of tunneling after the IPO. Cheung, Jing, and Lu (2009) find empirical evidence that public companies in Hong Kong perform asset tunneling through related party transactions.

A public company transacts assets with related parties at a higher price than on an asset transaction with an independent party. The
Company purchases assets from related parties at higher prices than on independent party transactions. However, the company sells assets to related parties at a lower price than to independent party transactions. The sale of assets to a related party below the fair price (tunneling out) will affect the financial performance but indirectly, through the loss of potential synergies between the assets in-tunnel and the remaining assets (Atasanov et al., 2007). Purchase of assets from related parties above the fair price (tunneling in) will reduce the profitability of the company. Purchasing assets above fair value increases the carrying amount of assets and increases depreciation expenses, so the joint effect will reduce return on assets. Therefore, through the application of control mechanisms to asset utilization through institutional ownership and debt policy, effectively and efficiently can control asset utilization so as to have a positive effect on company performance. Therefore, the indication of the transfer of resources out of the company through tunneling can be reduced. Therefore, a high increase in asset utilization will be in line with the high performance of the company as a result of the application of strong control mechanisms through institutional ownership and debt policy by the company. Some studies have found that asset utilization has a positive effect on company performance, among others: Wang, Goerge Yungchih (2010); Abdulla, Shah, and Khan (2012); and Pouraghajan, Tabari, Mansourinia, and Emamgholipour (2013).

\section{CONCLUSION}

The test result using simultaneous equation model shows that asset utilization has positive and significant effect to company perfor- 
mance. This shows that the higher asset utilization will affect the company's higher performance and the lower asset utilization will affect the company's lower performance. The implication of this research is that investors have an interest in funding and investment related to assets owned and managed within the company. Therefore, the improvement of asset utilization and company performance reflects the results of the company's planning, implementation, and control processes carried out by the company's managers of existing assets. Therefore, investors also need to evaluate the behavior of managers in making policies related to the utilization of corporate assets. On the other hand, investors also need to pay attention to the creditor's behavior in monitoring the financing given to the company and pay attention to the company's ability to pay interest and principal of maturing debt. In addition, owner behavior in changing ownership composition involving institutional ownership needs to be taken into account so that the trade-off between the expropriation effect and the monitoring effect due to changes in the behavior of the owner (majority shareholder) does not harm the investor because the tunneling activity can be done by the owner. The limitations of this study have not controlled and differentiated the sample based on the assumptions of high and low institutional ownership estimation models and high and low debt policies so that they can produce results that differ from those expected in the application of control mechanisms to the agency conflict. Subsequent research can consider the excess capacity of the use of assets owned by the company and the size of the company so as to maintain the level of efficiency of asset utilization.

\section{BIBLIOGRAPHY}

Abor, Joshua. 2007. Debt policy and performance of SMEs, Evidence from Ghanaian and South African firms. The Journal of Risk Finance, Vol. 8, No. 4, 2007, Page 364-379.

Ade, Yustina. 2007. Hubungan Struktur Kepemilikan dan External Monitoring Terhadap Agency Cost dan Aliran Kas. Jurnal Keuangan dan Perbankan, Vol.12, No.3, September, Page 343-354.

Aharony, et al. 2005. Related Party Transaction: A Real Means of Earning Management and Tunneling during IPO Processing China. Working Paper. University of Tel Aviv.

Ang, J.S., et al. 2000. Agency Cost and Ownership Structure. Journal of Finance, 55, Page 81-106.

Atasanov, et al. 2007. How Does Law Affect Finance An Examination of Financial Tunneling in an Emerging Market. Law and Economics Workshop, Page 1-64.

Bosses, et al. 2011. Governance Thresholds, Managerial Ownership, and Corporate Performance: Evidence from the U.K. Working Paper, No. 58, March.

Bozec, Y. dan Laurin, C. 2008. Large Shareholder Entrenchment and Performance: Empirical Evidence from Canada. Journal of Business Finance \& Accounting, 35, Page 25-49.

Chan, Wesley S. 2001. Stock Price Reaction to News and No-News: Drift and Reversal after Headlines.

Cheung, Y., et al. 2006. Tunneling, Propping and Expropriation: Evidence from Connected Party Transaction in Hongkong. Journal of Financial Economic, 82, Page 343-386. 
Cheung, Y.L., et al. 2009. Buy High, Sell Low: How Listed Firms Price Asset Transfers in Related Party Transactions. Journal of Banking and Finance, 335: Page 914-924. Cheung, Y.L., Jing, L.H., Lu., et al. 2009. Tunneling and Propping up: an Analysis of Related Party Transactions by Chinese listed companies. Pacific-Basin Finance Journal, 17 (3): Page 372-393.

Chen, J. 2001. Ownership Structure as Corporate Governance Mechanism: Evidence from Chinese Listed Companies. Economic of Planning, 34, Page 53-72.

Crutchley, C.E., et al. 1999. Agency Problem and the Simultaneity of Financial Decision Making: The Role of Institutional Ownership. International Review of Financial Analysis 8/2, Page 177-197.

Cui and Mak. 2002. The Relationship between Managerial Ownership and Firm Performance in High R\&D firms. Journal of Corporate Finance 8, Page 313-336.

Douma, S., et al. 2006. Foreign and Domestic Ownership, Business Groups, and Firm Performance: Evidence from a Large Emerging Market. Strategic Management Journal, 27, Page 637-657.

Ellis, R. 1998. Asset Utilization: A Metric for Focusing Reliability Efforts. Seventh International Conference on Process Plant Reliability. Marriot Houston Westside Houston, Texas. Oktober, Page 25-30.

Faccio and Lasfer. 1999. Managerial Ownership, Board Structure and Firm Value: The UK Evidence. Bilkent University and Hacettepe University Turkey.

Fleming, G., et al. 2005. Agency Cost and ownership structure in Australia. PacificBasin Finance Journal, 13, Page 29-52.
Gujarati, Damodar N. and Dawn C. Porter 2012. Dasar-Dasar Ekonometrika. Edisi 5, Jakarta: Salemba Empat.

Herdinata, Christian. 2006. ESOP (Employee Stock Ownership Program) Terhadap Reaksi Pasar dan Hubungannya dengan Kinerja Perusahaan yang Go Public di Bursa Efek Jakarta. Thesis Tidak Dipublikasikan, Pascasarjana Universitas Kristen Satya Wacana.

Hermeindito. 2004. Informasi Asimetri dan Kontrol Manajemen: Analisis Kepekaan Investasi dan Leverage Terhadap Pemilihan Sumber-Sumber Pendanaan. Disertasi Tidak Dipublikasikan, Pascasarjana Universitas Gadjah Mada.

Hermeindito. 2012. Leverage dan Nilai Perusahaan: Studi Empiris Pengujian Teori Pertukaran dan Teori Keagenan. Laporan Penelitian. Universitas Katolik Widya Mandala Surabaya.

Hu, Y. and Izumida, S. 2008. The Relationship between Ownership and Performance: A Review of Theory and Evidence. International Business Research, 1, Page 72-81.

Imam, M.O. and Malik, M. 2007. Firm performance and Corporate Governance through Ownership Structure: Evidence from Bangladesh Stock Market. International Review of Business Research Papers, 3, Page 88-110.

Ismiyanti, F. 2007. Biaya keagenan Pada Mikrostruktur Pasar: Pendekatan Rentang Harga. Disertasi tidak dipublikasikan, Pascasarjana Universitas Gadjah Mada.

Jelinek and Stuerke. 2009. The Nonlinear Relation between Agency Costs and Managerial Equity Ownership, Evidence of Decreasing Benefits of Increasing Owner- 
ship. International Journal of Managerial Finance, Vol. 5, No. 2, Page 156-178.

Jian, M. and Wong, T.J. 2010. Propping and Tunneling Thought Related Party Transaction. Review of Accounting Studies.

Johnson et al. 2000. Corporate Governance in Asian Financial Crisis. Journal of Financial Economic, 58, Page 141-186.

Morck, Randall, et al. 1988. Management Ownership and Market Valuation: An Empirical Analysis. Journal of financial Economics 20, Page 293-315.

Pouraghajan, et al. 2013. Investigation the Effect of Financial Ratios, Operating Cash Flows and Firm Size on Earnings per Share: Evidence from the Tehran Stock Exchange. International Research Journal of Applied and Basic Sciences.

Rayan, Kuben. 2008. Financial Leverage and Firm Value. A Research Project to the Gordon.

Ruan, et al 2011. Managerial Ownership, Capital Structure and Firm Value: Evidence from China's Civilian-Run Firms. Australasian Accounting Business and Finance Journal. Vol. 5, Bo. 3. 2011. Page 73-92. Shleifer, A. and Vishny, R.W. 1986. Large Shareholders and Corporate Control. Journal of Political Economy 94, Page 461-488.

Singh. M. and Davidson III W.N. 2003. Agency Cost, Ownership Structure and Corporate Governance Mechanism. Journal of Banking and Finance 27, Page 793-816.
Sulong, Z. and Nor, F.M. 2010. Corporate Governance Mechanisms and Firm Valuation in Malaysian Listed Firms: A Panel Data Analysis. Journal of Modern Accounting and Auditing, 6, Page 1-19.

Stephen, and David. 2009. Why Capital Efficiency Measures Are Rarely Used in Incentive Plans, and How to Change That. Journal of Applied Corporate Finance, Vol. 21, Page 87-92.

Thomsen, S. 2004. Block Holder Ownership, Dividends, and Firm Value In Continental Europe. Department of International Economics and Management, Copenhagen Business School.

Wang, George Yungchih. 2010. The Impacts of Free Cash Flows and Agency Costs on Firm Performance. Journal Service Science \& Management 3, Page 408-418.

Wellalege and Locke. 2011. Ownership Structure and Firm Financial Performance: Evidence from Panel Data in Sri Lanka. Journal of Business Systems, governance and Ethics. Vol. 7, No. 1.

Wiwattanakantang, Y. 2001. Controlling shareholders and corporate value: Evidence from Thailand. Pacific-Basin Finance Journal, 9, Page 323-362.

Zeitun and Tian. 2007. Does Ownership Affect a Firm's Performance and Default Risk in Jordan?. The International Journal of Business in Society, Vol. 7, No. 1, Page 66-82. 